American Journal of Applied Sciences 7 (5): 616-619, 2010

ISSN 1546-9239

(C) 2010Science Publications

\title{
The Potential of Extended Aeration System for Sago Effluent Treatment
}

\author{
${ }^{1}$ Wahi Abd Rashid, ${ }^{1}$ Hamdan Musa, ${ }^{2}$ Wong Sing King and ${ }^{3}$ Kopli Bujang \\ ${ }^{1}$ Department of Basic Science and Engineering, \\ ${ }^{2}$ Department of Animal Science and Fishery, \\ Faculty of Agriculture and Food Sciences, University Putra Malaysia, \\ Bintulu Campus, 97008 Bintulu, Sarawak, Malaysia \\ ${ }^{3}$ Department of Molecular Biology, Faculty of Resource Science and Technology, \\ University Malaysia Sarawak, 94300 Kota Samarahan, Sarawak, Malaysia
}

\begin{abstract}
Problem statement: Sago effluent contains large amount of organic material which has a potential to cause water pollution. In order to reduce this problem, an experiment was conducted to remove organic material from sago effluent using lab scale of Extended Aeration (EA) system. Approach: The EA system consisted of the combination of physical and biological treatment unit. For Physical Treatment Unit (PTU), the sago effluent was filtered using $710 \mu \mathrm{m}$ mesh size filter. For Biological Treatment Unit (BTU), the effluent were mixed and aerated with activated sago sludge for $48 \mathrm{~h}$. The treatment efficiency with respect to Biological Oxygen Demand (BOD), Chemical Oxygen Demand (COD) and Total Suspended Solid (TSS) removal were evaluated and compared with regulatory requirement by Department of Environment, Malaysia. Results: The result showed, the EA system could reduce BOD, COD and TSS up to $84,87.8$ and $73 \%$ respectively, however it did not comply with the regulatory requirement. Conclusion: This study suggested the EA system have potential to be apply on sago effluent, however it should be integrated with additional treatment unit to achieve the effluent quality standard.
\end{abstract}

Key words: Sago effluent, EA, BOD, COD, TSS

\section{INTRODUCTION}

EA system is a modified version of the activated sludge process whereby the effluent is maintained under long term Hydraulic Retention Time (HRT) and high concentration of Mixed Liquor Suspended Solid (MLSS). Under these conditions, the organism are starved and forced to degrade high organic substances in the effluent (Environmental Institute of Malaysia, 2007). This system has a potential to be apply on sago effluent treatment which contains high concentration of BOD, COD and TSS (Savitha et al., 2009; Chew and Shim, 1993).

Previous study by Bujang et al. (2005) reported that by removing the sago hampas from primary effluent could reduce TSS up to $70 \%$. According to Environmental Institute of Malaysia (2007), the elimination of bulky waste from primary effluent could stabilize the effluent and increase the treatment efficiency. Meanwhile, Bujang et al. (2005) reported that the intermittent aeration of filtered sago effluent could increase the COD removal. According to Environmental Institute of Malaysia (2007) the treatment process using EA system is more effective under desirable MLSS.

The information and finding from those studies could be use to modify and improved the available EA system for sago effluent treatment. Therefore this study was conducted to evaluate the effectiveness of EA system for sago effluent treatment. In this study, the HRT was set within $48 \mathrm{~h}$. Continuous aeration system were use and the effluent were mixed with sago activated sludge to increase the degradation process. The removal of BOD, COD and TSS were evaluate to determine the treatment efficiency.

\section{MATERIALS AND METHODS}

Primary sago effluent was collected from large sago mill (Nitsei Sago Industries Pte. Ltd) in Mukah Sarawak and were transported to the laboratory using 200 L PVC tank. The effluent then were filtered using

Corresponding Author: Wahi Abd Rashid, Department of Basic Science and Engineering, Faculty of Agriculture and Food Sciences, University Putra Malaysia Bintulu Campus, 97008 Bintulu, Sarawak, Malaysia 
$710 \mu \mathrm{m}$ mesh size filter to separate it from sago hampas. The filtered effluent then were aerated for $48 \mathrm{~h}$ in $100 \mathrm{~L}$ aeration tank to cultivate the sludge. After aeration process, the aerated effluent were transferred into sedimentation tank and the sludge were allowed to settle down for $10 \mathrm{~h}$ by gravity. About $50 \%$ of the sludge were mixed with $50 \mathrm{~L}$ of aerated and $50 \mathrm{~L}$ filtered effluent and aerated for $48 \mathrm{~h}$. The treatment process were complete after final effluent were transferred into final clarifier.

The concentration of BOD, COD and TSS in primary, filtered, aerated and final effluent were measured following the procedure of Greenberg (1995) and the treatment efficiency were calculated according to the following formula (Nathanson, 2003):

$$
\mathrm{TE}=\frac{\mathrm{P}_{\mathrm{IN}}-\mathrm{P}_{\mathrm{OUT}}}{\mathrm{P}_{\mathrm{IN}}} \times 100
$$

Where:

$\mathrm{TE}=$ Treatment efficiency

$\mathrm{P}_{\mathrm{IN}}=$ Concentration of pollutant flowing into the treatment system

$\mathrm{P}_{\text {OUT }}=$ Concentration of pollutant flowing out of the system

The result were compared to Industrial Wastewater Quality Standard (IWQS) referred from Environmental Quality Act (Department of Environment,1974) under Sewage and Industrial Effluents Regulations (SIER), 1979 (Standard B).

\section{RESULTS}

Figure 1 showed the concentration of BOD in primary, filtered, aerated and final effluent was decreased from 1038.75-675.19, 471.5 and $170 \mathrm{mg} \mathrm{L}^{-1}$ respectively. Meanwhile Fig. 2 showed the treatment efficiency of BOD in primary, filtered, aerated and final effluent were increased from 0-35, 55 and 84\% respectively.

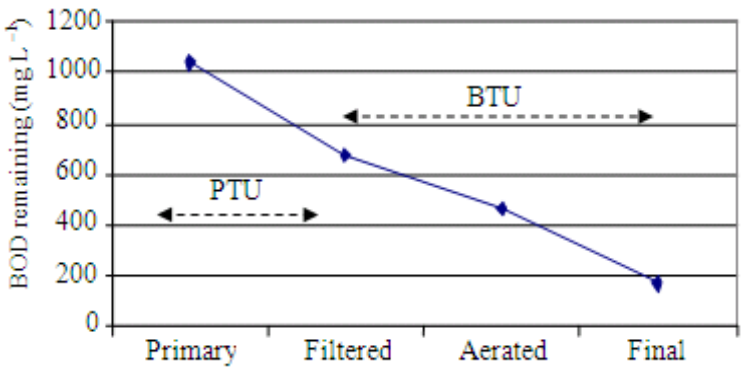

Fig. 1: BOD remaining in primary, filtered, aerated and final effluent
Figure 3 showed the concentration of COD in primary, filtered, aerated and final effluent were decrease from 3992-3890, 675.33 and $486.67 \mathrm{mg} \mathrm{L}^{-1}$ respectively. Figure 4 showed the highest removal of COD occur during the treatment in BTU which removed about $85.3 \%$ compared to PTU which only remove $2.5 \%$ of COD.

Figure 5 showed the concentration of TSS in primary, filtered and aerated effluent was decreased from $2900-870$ and $672 \mathrm{mg} \mathrm{L}^{-1}$ respectively. However the concentration of TSS in Final effluent was increase to $786 \mathrm{mg} \mathrm{L}^{-1}$. Figure 6 showed the highest removal of TSS also occur at PTU with the treatment efficiency was $70 \%$. The removal percentage then slightly increase to $77 \%$, but decrease to $73 \%$ during the treatment process in BTU.

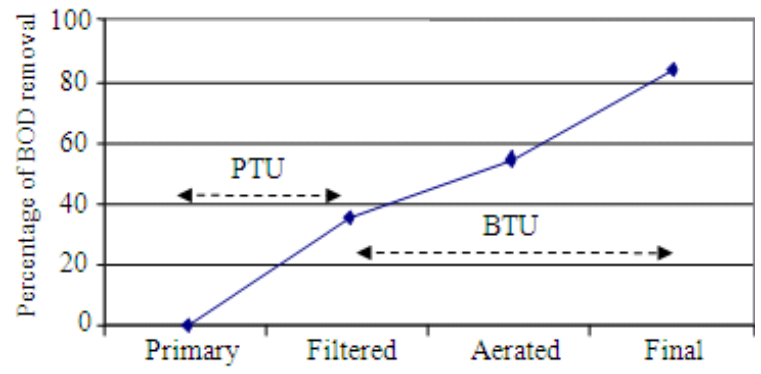

Fig. 2: The removal percentage of BOD in primary, filtered, aerated and final effluent

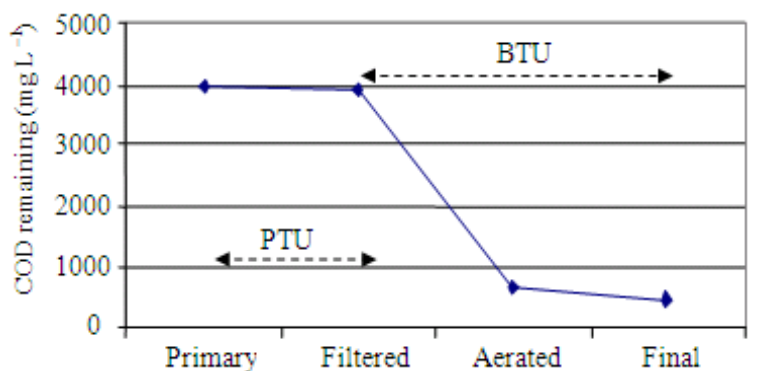

Fig. 3: COD remaining in primary, filtered, aerated and final effluent

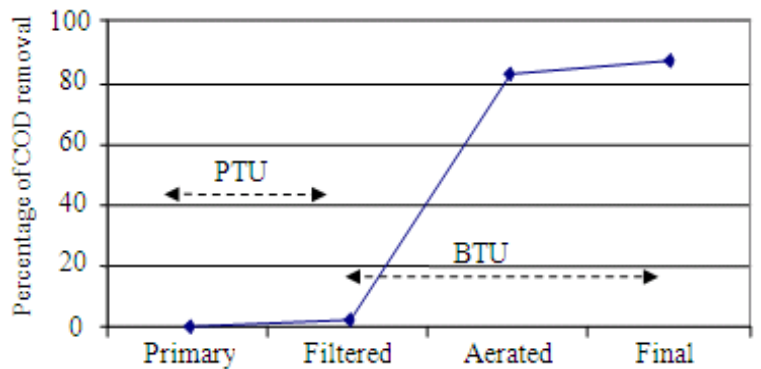

Fig. 4: The removal percentage of COD in primary, filtered, aerated and final effluent 
Am. J. Applied Sci., 7 (5): 616-619, 2010

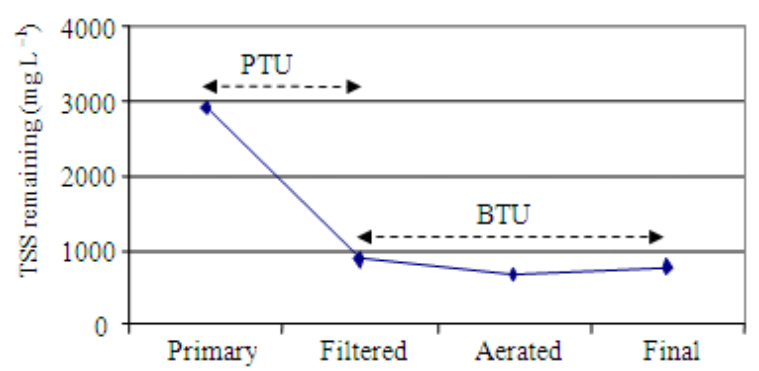

Fig. 5: TSS remaining in primary, filtered, aerated and final effluent

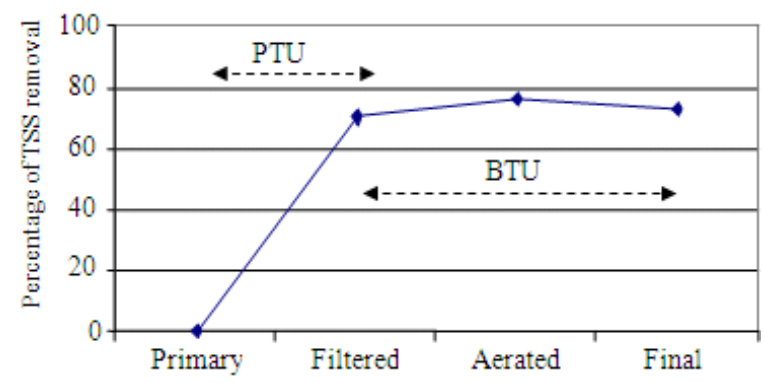

Fig. 6: The removal percentage of TSS in primary, filtered, aerated and final effluent

\section{DISCUSSION}

The characteristic of primary Sago effluent: The concentration of BOD, COD and TSS in primary effluent were 1038.75, 3992 and $2900 \mathrm{mg} \mathrm{L}^{-1}$ respectively. Previous study by Phang et al. (2000); Bujang et al. (2005) and Ibrahim et al. (2006) reported the BOD, COD and TSS in primary effluent could be range from 910-1300, 780-5130 and 19-20000 $\mathrm{mg} \mathrm{L}^{-1}$ respectively. Those range certainly did not comply with the regulatory requirement of Department of Environment (1974). Therefore the effluent need to be treated before being discharge into watercourse.

BOD removal: Through the treatment process using EA system, about $35 \%$ of BOD were removed through PTU. There is no information about BOD removal on sago effluent, through PTU from previous study, however according to Nathanson (2003), the elimination of bulky waste in domestic wastewater could reduce BOD up to $35 \%$.

Generally the BOD removal in BTU is higher compared to PTU. According to Bujang et al. (2005), the removal of sago hampas could stabilize the $\mathrm{pH}$ level of the effluent. With the continuous of air supply, the microbial growth was increase thus accelerated the degradation of sago effluent. Although the removal of
BOD could be consider high up to $84 \%$ or $170 \mathrm{mg} \mathrm{L}^{-1}$, however it still could not be release into the watercourse as the effluent quality did not comply with the standard limit by Department of Environment (1974).

COD removal: According to the result shown in Fig. 4, it clearly showed that COD removal is significantly occur during the treatment in BTU which removed about $85.3 \%$ compare to PTU which remove only $2.5 \%$ of COD. This indicates that the PTU is less effective in COD removal compare to BTU. This could be due to the high fibre and organic solid contents of the unfiltered effluent which slows the degradation process (Bujang et al., 2005),

Although the removal of COD is high at $87.8 \%$ or $486.67 \mathrm{mg} \mathrm{L}^{-1}$, but it did not comply with the regulatory requirement. Therefore further study should be carried out to improve the treatment efficiency of EA system to achieve the effluent quality standard.

TSS removal: Figure 6 show the removal of TSS is significantly occur during the treatment through PTU at $70 \%$. This also supported from previous study by Bujang et al. (2005) which reported that the removal of sago hampas could reduce TSS to $70 \%$.

Furthermore, the concentration of TSS during the treatment through BTU was fluctuated which may be due to 2 reason: (1) during the pre-aerated of sago effluent the concentration of TSS has decrease to $7 \%$ (from 870-672 $\mathrm{mg} \mathrm{L}^{-1}$ ) however when the sago sludge were added with sago effluent the concentration of TSS has increase to $17 \%$ (from $672-786 \mathrm{mg} \mathrm{L}^{-1}$ ), (2) the degradation of sago effluent during the treatment in BTU also produce sludge which change the concentration of MLSS.

Compared with the effluent quality standard, the concentration of TSS in final effluent is 7 times higher than permissible limit. Therefore the effluent did not comply with the regulatory requirement and could not be release to watercourse.

\section{CONCLUSION}

The use of EA system in sago effluent treatment could reduce BOD, COD and TSS at 84,88 and $73 \%$ respectively. However the final effluent did not comply the regulatory requirement of Department of Environment (1974). Therefore it could be concluded that the EA system has a potential to be apply on sago effluent, however further study on additional treatment unit should be carried out to improved the treatment efficiency to achieve the effluent quality standard. 


\section{ACKNOWLEDGEMENT}

The researcher thank to University Putra Malaysia for providing financial support under Research University Research Grant Scheme (RUGS) 91453. Thanks also to Siren Anak Linggang, Nurul Wahida Hani and Mohammad Tarmizi Abdul Razak for their assistance during the field and laboratory work.

\section{REFERENCES}

Bujang, K.B., M.A. Yusop and K. Sonomoto, 2005. Degradation of sago effluent by aerobic methods. Unimas RIMC Res. Paper Ser., 1: 45-50.

Chew, T.Y. and Y.L. Shim, 1993. Sago Processing Wastes. In: Waste Management in Malaysia. Current Status and Prospects for Bioremediation, Yeoh, B.G., S.M. Phang, Z. Isa, A. Idris and M. Mohamed (Eds.). Ministry of Science, Technology and the Environment, Malaysia, pp: 159-167.

Department of Environment, (DOE), 1974. Environmental Quality Act, 1974. Department of Environment, Malaysia.

Environmental Institute of Malaysia, (EiMAS), 2007. Training Course Module on Certification Course for Operators of Industrial Effluent Treatment System (IETS). Environmental Institute of Malaysia, Department of Environment, Malaysia.
Greenberg, A.E., 1995. Standard Methods for Examination of Water and Wastewater. 19th Edn., American Public Health Association, Washington DC., USA, pp: 1325.

Ibrahim, S., S. Vikineswary, S. Al-Azad and L.L. Chong, 2006. The effects of light intensity, inoculum size and cell immobilization on the treatment of sago effluent with Rhodopseudomonas palustris Strain B1. Biotechnol. Bioproc. Eng., 11: 377-381. DOI: 10.1007/BF02932303

Nathanson, J.A., 2003. Basic Environmental Technology: Water Supply, Waste Management and Pollution Control. 4th Edn., Prentice Hall, New Jersey, pp: 535.

Phang, S.M., M.S. Miah, B.G. Yeoh and M.A. Hashim, 2000. Spirulina cultivation in digested sago starch factory wastewater. J. Applied Phycol., 12: 395400. DOI: 10.1023/A:1008157731731

Savitha, S., S. Sadhasivam, K. Swaminathan and F.H. Lin, 2009. A prototype of propose treatment plant for sago factory effluent. J. Cleaner Prod., 17: 1363-1372. DOI: 10.1016/j.jclepro.2009.03.021 